Journal of Business and Tourism

Volume 06 Number 01

January - June, 2020

\title{
Moderating Role of Leaders' Emotional Intelligence in Job Characteristics and Employees' Organizational Citizenship Behavior Relationship: Evidence from Construction Sector of Pakistan
}

\author{
Muhammad Asadullah \\ Assistant Education Officer, School Education Department Punjab \\ asadmpa@gmail.com \\ Dr. Kamran Azam \\ Assistant professor, National DefenceUniversity, Islamabad \\ Kamranazam.khan@gmail.com \\ Rohi Mehnaz \\ PhD Scholar, Baha-ud-Din Zakariya University, Multan \\ mehnazruhi@yahoo.com \\ Dr. Mujahid Hussain \\ National University of Computer and Emerging Sciences, Lahore \\ Mujahid.hussain@nu.edu.pk
}

\begin{abstract}
The present study investigates the moderating role of leaders' EI on Oldham and Hackman's Job Characteristics and Employees' OCB relationship in construction sector of Pakistan. Questionnaires were completed by 187 participants employed in private construction sector organizations in Islamabad using simple random sampling. Linear Regression Model was applied to predict the value of the dependent variable 'OCB' on the basis of independent variables Task Significance, Skill Variety, Task Identity, Job Autonomy and Feed-Back. Stepwise Multiple Regression Model was applied to test the moderating effect of EI in OCB-JC relationship. On the basis of the results, it was established that employees' $O C B$ can be significantly predicted based upon core job characteristics of Hackman \& Oldham (1976). It was further established that leaders' EI moderates the Job Characteristics - OCB relationship.
\end{abstract}

Key words: Emotional Intelligence, Organizational Citizenship Behavior, Job Characteristics Theory

\section{Introduction}

Organizations strive to increase their return on investment through productive work performance of their employees. In addition to formal job requirements, organizations 
may strive to seek the extra role performance of their employees for this purpose (Maric, Hernaus, Tadic, \& Cerne, 2019; Johari \& Yahya, 2009). Recent studies suggest that highly motivated employees exhibit increased job performance beyond their defined role which is called organizational citizenship behaviors (OCB). Studies suggest that enriching jobs by placing more emphasis on job characteristics as outlined by Hackman \& Oldham (1976) are instrumental in motivating individuals to work beyond their defined role (Chiu \& Chen, 2005; Chen \& Chiu, 2009) and may benefit the organizations (Maric et al., 2019). Moreover, well defined jobs and leaders' emotional intelligence (EI) is considered instrumental to motivate the employees to exhibit OCB (Choerrudin, 2016; Parker, Wall, \& Cordery, 2001). Emotionally intelligent executives as well as employees can understands emotions of their own and that of others and can shape positive extra role behaviors (OCB) among the employees (Lindebaum \& Cassell , 2012). Research suggests that emotionally intelligent managers may ignite OCB among employees if their jobs are wisely designed and roles are clearly defined (Parker et al., 2001 \& Lindebaum \& Cassell , 2012). This suggests that EI and job characteristics when combined may prove instrumental in display of OCB among employees.

In this study we have investigated the direct relationship of core job characteristics of Hackman \& Oldham (1975) with employees' OCB. Further, we have also tested the moderating role of emotional intelligence in job characteristics and job performance relationship. We employed Job Design Theory of Hackman \& Oldham (1975) to test the direct as well as moderating impact of independent variables on dependent variables. JCM proposes five core job features that produce three psychological states in employees and these psychological states ultimately result in certain outcomes that are beneficial to the individual and the organization as well.

\section{Literature Review}

\section{Job Characteristics and OCB}

Last three decades witnessed a substantial attention of researchers to make advancement in both theory and practice in the area of Job Design (Grant, Fried, Parker, \& Frese, 2010). This area of broader scope has got vital importance for the inception of new project, organizational restructuring, and changing the target market and above all, to enhance the employee as well as organizational performance (Grant, Fried, Parker, \& Frese, 2010; Morgeson, Medsker, \& Campion, 2006). Research suggests that well designed motivating job characteristics may increase display of OCB among employees (Chen \& Chiu, 2009; Piccolo \& Colquitt, 2006). Jobs that are structured and well defined are instrumental in persuading the employees perform well and exhibit OCB (Kuehn \& Al-Busaidi, 2002; Krishnan, et al., 2010). Evidence from studies of Unuvar (2006) and Piccolo \& Colquitt (2006) suggest that job characteristics such as skill variety, task identity, task significance, autonomy and feedback are not only instrumental to OCB and organizational performance, but these also contribute employees' job satisfaction which again is predictor of employees' job performance. Core job characteristics ignite contextual job performance (OCB) which is source of competitive advantage to promote 
responsiveness in enhancing overall organizational effectiveness (Liguori, McLarty, \& Muldoon, 2013; Johari \& Yahya, 2009).

Irrespective of the promising impacts of job characteristics on OCB of employees, studies show that jobs in construction sector are ill defined and less motivating which adversely affect OCB of construction sector employees (Ling \& Loo, 2013) which is deterimental to the overall productivity and profitability of the organization. It is evidents from the research (Maloney \& McFillen, 1986) that construction jobs have low motivating potentional. Hence there is dire need to redesign the jobs in construction sector which may have higher motivating potentional to make the employees display increased contextual job performance.

Although Job Characteristics and OCB remained widely researched variables in broader domains of organizational behavior and organizational psychology however, recent research suggests that most of the studies mainly focused task performance. Effects of contextual job performance on overall performance of employees have been paid little attention (Johnson, 2001). Further, major chunk of research in this area has been limited to Western context and we found weaker input on this domain from the Non-Western context (Kuehn \& Al-Busaidi, 2002; Krishnan, et al., 2010). While contextualizing these two variables, we found a very few studies in construction sector on the relationship between Job Characteristics and OCB (Onukwube \& Iyagba, 2011). Hence, there exists a research deficit which needs to bridged. We assume that core job characteristics of Hackman \& Oldham (1975) have positive impact on organizational citizenship behavior of employees in construction section in Pakistan. We propose that;

H1: Job Characteristics are positively related to Organizational Citizenship Behavior of employees in construction sector of Pakistan.

\section{Emotional Intelligence and OCB}

Over the past few decades Emotional intelligence (EI) research witnessed tremendous growth because it is considered as an essential factor in organizational setup (Antony, 2013). Studies suggest that EI is strong predictor of employees' is organizational citizenship behavior which further predicts overall organizational performance (Jain, 2012; Malik, Danish, \& Munir, 2012). Emotional intelligence is the ability to perceive accurately, appraise, and express emotion; the ability to access and/or generate feelings when they facilitate thought; the ability to understand emotion and emotional knowledge; and the ability to regulate emotions to promote emotional and intellectual growth. Goleman(1998) suggests EI is instrumental is instrumental for individual as well as organizational well being. He asserted that EI is 70 times more important general intelligence for success in every walk of life. His model links EI with work place success instead of Bar-On conception of EI, who links it with general wellbeing (Antony, 2013). Although EI is instrumental for individual as organizational productivity and performance, studies suggest that construction employees are low at emotional intelligent scale as compared to employees working in other sectors (Dulewicz \& Higgs, 2000; Smyth, 2004; Mo, Dainty, \& Price, 2007; Songer, Chinowsky, \& Butler, 2008). For 
better performance, along with other factors, construction executives require higher emotional intelligence level (Songer, Chinowsky, \& Butler, 2008). By developing emotional intelligence among the construction executives, the performance of the project employees and the overall project as well can be improved (Cacamis \& EI Asmar, 2014). Hence, a ddire need is felt to empirically test the impact of emotional intelligence on organizational citizenship behavior of construction sector employees (Lindebaum \& Cassell , 2012; Mo, Dainty, \& Price, 2007). This clearly suggests that there exists a contextual gap in job performance and EI domain and we propose that;

H2: Leaders' EI is positively related to Organizational Citizenship Behavior of employees in construction sector of Pakistan.

\section{Moderating Role of Emotional Intelligence in Job Characteristic and OCB Relationship}

Over the past three decades, Job design, job performance and the relation of these two variables has been a widely researched area in organizational behavior and psychology. However the main focus of this research remained job characteristics and job performance relation but probable moderators of this relation lacked the attention of the researchers (Parker, Wall, \& Cordery, 2001; Ali, 2009). Moreover, study of job performance remained restricted to task performance neglecting effects of contextual job performance on overall performance of employees (Johnson, 2001). Lindebaum \& Cassell (2012) argue that emotional intelligence is predictor of job performance but its relation with job characteristics and contextual job performance lacks the attention of researcher in general and specially in construction sector. Further, Ali (2009) also psoits that moderating role of emotional intelligence on job characteristics and organizational citizenship behavior (OCB) relationship needs empirical evidences.

Studies suggest that construction sector is neglected sector in underdeveloped and developing countries like Pakistan. It has low growth and falling potential at GDP because workforce engaged in this sector is least productive. Maloney \& McFillen(1995) argue that the reasons for low productivity of construction employees are that although construction jobs have stronger Growth Need Strength (GNS) but these are less structured and low at motivational potential. Hence there is dire need to redesign the jobs in construction sector (Maloney \& McFillen, 1986).Moreover, studies suggest that construction workers are low at emotional intelligent scale as compared to employees working in other sectors which is significant reason of low growth of construction sector (Dulewicz \& Higgs, 2000; Smyth, 2004; Mo, Dainty, \& Price, 2007; Songer, Chinowsky, $\&$ Butler, 2008). Similarly, we found weaker evidences of studies on job characteristics, OCB and EI have been conducted in western world neglecting Non-Western context ( Karim \& Weisz, 2010). Thus we believe that there are sufficient evidences suggesting modeling of all the three variables together. In view of this, we aimed to study the moderating role of emotional intelligence on job characteristics and OCB relationship in construction sectors of Pakistan. We assume that; 
H3: Leaders' EI positively moderates the Job characteristics - Organizational Citizenship Behavior relationship of employees in construction sector of Pakistan.

\section{Methods}

Keeping in view the data type, quantitative technique was adopted to study the relationship in construction sector of Pakistan because this techniques best suit to study cause-effect relationships. Data were collected from 375 knowledge construction workers using simple random sampling. Data were analyzed through SPSS Version 26 using correlations and simple linear and multiple regression analysis which included main effects and moderation analysis.

\section{Instrument}

A combined 64 items scale was used to measure the study variables. Five job characteristics of Hackman \& Oldham's (1976) JCM were measured using 15 items scale used by Hunter (2006). Emotional Intelligence of the leaders was measured using 33 items self-report measures used by Ali (2009) who adopted it from Schutte et al. (1998). Employees' OCB was measured using 16 items scale used by Shahzad (2011) who based it from Podsakoff et al. (1990). A 5-point Likert scale was used to collect responses for the main variables.

\section{Results and Discussion}

A total of 375 questionnaires were distributed among knowledge construction workers of Islamabad using simple random sampling. However, 198 questionnaires were returned back giving a response rate of 53\%. Moreover, 11 questionnaires were excluded as these were incomplete. Hence response rate reduced to $50 \%(\mathrm{n}=187)$ which is quite satisfactory as $37 \%$ response rate has been reported in similar studies like Ali (2009).

\section{Correlation Analysis}

Table 1: Results of Correlation Analysis

\begin{tabular}{cccccc}
\hline & Mean & Std. Deviation & OCB & EI & JC \\
\cline { 1 - 2 } & 1.36 & .314 & 1 & & \\
EI & 1.61 & .194 & $.523^{* *}$ & 1 & \\
JC & 1.69 & .638 & $.376^{* *}$ & $.612^{* *}$ & 1 \\
\hline
\end{tabular}

significant at the 0.01 level (2-tailed).

$O C B=$ Organizational Citizenship Behavior, EI= Emotional Intelligence, $J C=J o b$

Characteristics

The correlation analysis indicates that core job characteristics i.e. Task Significance, Skill Variety, Task Identity, Job Autonomy and Feedback have significant positive relationship with organizational citizenship behavior of employees. It also depicts a significant relationship between leaders' emotional intelligence and employees' organizational citizenship behavior. 


\section{Regression Analysis}

Linear regression analysis was applied to predict the value of the dependent variable 'OCB' on the basis of independent variable job characteristics (task significance, skill variety, task identity, job autonomy and feed-back). Stepwise Multiple Regression Model was applied to test the moderating effect of emotional intelligence in job characteristics and organizational citizenship behavior relationship.

Table 2: Moderated regression analysis of EI on Job Characteristics-OCB

\section{Relationship}

Organizational Citizenship Behavior

B $\quad \Delta \mathrm{R}^{2}$

\section{Step 1}

Gender

0.02

0.00

Step 2

Job Characteristics (A)

$0.19 *$

Emotional Intelligence (B)

$0.23 * *$

$0.02 * * *$

\section{Step 3}
$\mathrm{B} \times \mathrm{C}$
$0.16^{*}$
$0.09 *$

Multiple linear regression analysis was used to test all main effect hypotheses. Regression results for main effects of Job Characteristics and Emotional Intelligence on Organizational Citizenship Behavior are reported in Table 2. For main effects, gender was entered in the first step and all independent variables were entered in the second step. Results indicated that Job Characteristics were positively related to OCB $\left(\beta=0.19^{* *}\right.$, $\mathrm{p}<0.05)$. These results support hypothesis $\mathrm{H} 1$ for Job Characteristics only. Results also indicated that Emotional Intelligence was positively related to OCB $(\beta=0.23, \mathrm{p}<0.05)$. These results support Hypothesis $\mathrm{H} 2$ for EI only.

Moderated regression analysis (Cohen et al. 2003) was used to test hypotheses H3. For this purpose, we entered the independent and moderating variables. Gender as control variable was entered in the first step. Independent and moderating variables were entered in the second step. In the third step, product terms of independent and moderator variables (Job Characteristics $\times$ Emotional Intelligence) were entered, which if significant confirmed moderation. Results in Table 2 show that the interaction term of Job Characteristics $\times$ Emotional Intelligence was significant for $\operatorname{OCB}(\beta=0.16, p<0.05)$. EI moderated the relationship between Job Characteristics and OCB. Therefore hypothesis H3 was supported. 


\section{Discussion on Results}

\section{Job Characteristics and Employees' OCB}

So far as the impact of major job characteristics on employees' OCB in constructions sector of Pakistan, results of correlation and linear regression analysis in tables $1 \& 2$ clearly indicate that there is significant positive relationship between core job characteristics and employees' organizational citizenship behavior in construction sector of Pakistan. These findings are consistent with the findings of Unuvar (2006) and Ispas \& Borman(2008), Ali (2009), Ozturk (2010), Jelstad (2010), Onukwube \& Iyagba (2011) and Zareen, et al. (2013) who found that job characteristics predict the employees' level of OCB. Further, Ispas \& Borman (2008) found that job characteristics like autonomy, skill variety and feed-back positively affect the organizational citizenship behavior of employees. This confirms the $1^{\text {st }}$ hypothesis that Job Characteristics are positively related to Organizational Citizenship Behavior of employees in construction sector of Pakistan.

\section{EI and Employees' OCB:}

The results of bivariate correlation and linear regression analysis in table 1 \&2clearly indicate that there is significant positive relationship between leaders' emotional intelligence and employees' organizational citizenship behavior in construction sector of Pakistan.

Results of the current study are also consistent with the findings of Korkmaz \& Arpaci (2009), Ali (2009), Zhou (2010), Naseer et al. (2011). They found that that EI strongly affects employees' OCB in positive manner. Hence hypothesis 'Leaders' EI is positively related to Organizational Citizenship Behavior of employees in construction sector of Pakistan" is accepted.

\section{Moderating Role of EI in Job Characteristics and OCB Relationship}

The third hypothesis that leaders' EI positively moderates the relation between core job characteristics and employees' OCB was fully supported. The results of regression analysis at table 2 shows that five core Job Characteristics of Hackman \& Oldham Model positively affect employees' OCB in construction sector (23\% variation in OCB) through Leader's EI. No previous empirical work was found to study the moderating role of job Moderating Role of Job Characteristics autonomy in the EI-performance relationship.

\section{Conclusions}

This study contributes to the momentum gaining body of knowledge on Job Characteristic Theory of Hackman \& Oldham (1976)and how core job characteristics can help to develop organizational citizenship behavior among the employees. This also helps in understanding the moderating role of leaders' EI in Job Characteristics and employees' OCB relationship. This study based on a sample from construction sector of Pakistan, confirmed that core job characteristics i.e. task significance, skill variety, task identity, job autonomy and feedback lead positively and significantly to the development of OCB among employees in construction sector. This also confirms that leaders' EI positively 
and significantly moderate Job Characteristics and employees' OCB relationship in construction sector of Pakistan.

\section{Implications \& Further Research}

Results of the current study revealed that well defined jobs motivate the employees to exhibit OCB. It has also been found that leaders' EI is an important factor that shapes employees' OCB. These results are consistent with the findings are Sunindijo, Hadikusumo, \& Ogunlana (2007) \& Korkmaz \& Arpaci(2009). The results are also consistent with the findings of Lawler et al. (1973)who found that after introducing interventions at Telephone Company of USA, employees showed better performance because of two dimensions of jobs i.e. job autonomy and skill variety. These results were also supported by Morgeson et al.(2006). Hence managers should give due considerations to the core job characteristics of Hackman \& Oldham (1976) while designing jobs of construction employees.

The results of the study are also helpful for HR practitioners. They may design the construction jobs and training programs to enhance the EI of construction employees. This was also recommended by Fatt (2002), Sunindijo \& Hadikusumo (2014) and Dulewicz \& Higgs (2000).

As a result of the research, it can be argued that a clear understanding of the concept of job design and core job characteristics of Hackman \& Oldham (1976) may guide managers in terms of making better decisions in relation to employee selection, placement, training, development, transfer, promotion and retention by making a proper match between each employee and his/her job.

An understanding of the importance EI in work setting may help the managers to develop human resources into a more positive and committed work by employing emotionally intelligent executives.

The study has also some implications for policy maker, especially for educationist. Zhou(2010) has suggested the use of EI as a criterion for the selection of students to be future engineers. He concluded that professional readiness can be promoted by emotionally intelligent engineers. This will also help academicians while developing the curriculum for construction engineers to enhance their academic/work performance.

Although core job characteristics of Hackman \& Oldham (1976) and EI have exhibited high explanatory power in the development of $\mathrm{OCB}$, yet the current research leaves certain areas unexplored.

The current study measures only the association and predictive relationship for Job Characteristics -OCB relationship in the private construction sector. Future studies may validate the relation by researching in the public construction sector. This relation may also be studied in other sectors like education, banking and heath sectors etc.

Current study used a self-report measure of EI that correlates with the existing measures of personality. Future researches may go for an ability based EI measure (MSCEIT). 


\section{References}

Ali, A. (2009). The Moderating Role of Job Characteristics on Emotional Intelligence and Performance. Islamabad: Foundation University.

Antony, J. M. (2013). The Influence of Emotional Intelligence on Organizational Commitment and Organizational Citizenship Behavior. International Journal of Social Science \& Interdisciplinary Research , 110-115.

Cacamis, M., \& EI Asmar, M. (2014). Improving Project Performance through Partnering and Emotional Intelligence. Practice Periodical on Structural Design and Construction, 50-56.

Chen, C.-C., \& Chiu, S.-F. (2009). The Mediating Role of Job Involvement in the Relationship between Job Characteristics and Organizational Citizenship Behavior. The Journal of Social Psychology , 474-494.

Chiu, S.-F., \& Chen, H.-L. (2005). Relationship between Job Characteristics and Organizational Citizenship Behavior: The Mediating Role of Job Satisfaction. Social Behavior and Personality An International Journal , 523-540.

Choerrudin, A. (2016). The effect of Emotional Intelligence on Job Performance and Turnover Intention: An Empirical Study. Polish Journal of Management Studies, 51-62.

Dulewicz, V., \& Higgs, M. (2000). Emotional intelligence - A review and evaluation study. Journal of Managerial Psychology , 15 (4), 341-372.

Fatt, J. P. (2002). Emotional Intelligence: For Human Resource Managers. Management Research News , 25 (11), 57-74.

Goleman, D. (1998). What Makes a Leader? Harvard Business Review .

Grant, A. M., Fried, Y., Parker, S. K., \& Frese, M. (2010). Putting job design in context:Introduction to the special issue. Journal of Organizational Behavior, 145-157.

Hackman, J. R., \& Oldham, G. R. (1976). Motivation through the design of work: Test of a theory. Organizational behavior and human performance , 2 (16), 250-279.

Hunter, P. E. (2006). Viability Of the Job Characteristics Model In A Team Environment: Prediction Of Job Satisfaction And Potential Moderators. PhD Thesis, UNIVERSITY OF NORTH TEXAS.

Ispas, D., \& Borman, W. C. (2008). Beyond task performance: the concept of organizational citizenship performance. Psihologia Resurselor Umane , 12-18.

Jain, A. K. (2012). Moderating Effect of Impression Management on Relationship of Emotional Intelligence and Organizational Citizenship Behavior. Journal of Behavior and Applied Management, 86.

Jelstad, B. (2010). Job characteristics and its outcomes-A comparative work design study of non-profit and profit organizations.

Johari, J., \& Yahya, K. K. (2009). Linking Organizational Structure, Job Characteristics and Job Performance Construct: A Proposed Framework. International Journal of Business and Management, 145-152. 
Johnson, J. W. (2001). The Relative Importance of Task And Contextual Performance Dimensions to Supervisor Judgement of Overall Performance. Journal of Applied Psychology , 86 (5), 984-996.

Karim, J., \& Weisz, R. (2010). Cross-Cultural Research on the Reliability and Validity of the Mayer-Salovey-Caruso Emotional Intelligence Test (MSCEIT). CrossCultural Research, $X X(\mathrm{X})$, pp. 1-31.

Kirkman, B. L., \& Shapiro, D. L. (1997). The Impact Of Cultural Values On Employee Resistance To Teams: Toward A Model Of Globalized Self-managing Work. Academy ol Management Review , 22 (3), 730-757.

Korkmaz, T., \& Arpaci, E. (2009). Relationship Of Organizational Citizenship Behavior With Emotional Intelligence. World Conference on Educational Sciences, (pp. 2432-2435).

Krishnan, R., Omar, R., Imsail, I. R., Alias, M. A., Hamid, R. A., Ghani, M. A., et al. (2010). Job Satisfaction as a Potential Mediatir between Motivational Job Characteristics and Organizational Citizenship Behavior: Evidence from Malaysia. Journal of Information Technology and Economic Development .

Kuehn, K. W., \& Al-Busaidi, Y. (2002). Citizenship Behavior in Non-Western Context: An Examination of the Role of Satisfaction, Comittment and Job Characteristics on Self-Reprted OCB. International Journal of Commerce and Management, 107-126.

Lawler, E., Hackman, J. R., \& Kaufman, S. (1973). Effects of Job Redesign: A Field Experiment. Journal of Applied Social Psychology, 3 (1), 49-62.

Liguori, E. W., McLarty, B. D., \& Muldoon, J. (2013). The Moderating Effect of Percieved Job Characteristics on the Proactive Personality-Organizational Citizenship Behavior. Leadership \& Organizational Development Journal .

Lindebaum , D., \& Cassell , C. (2012). A Contradiction in Terms? Making Sense of Emotional Intelligence in a Construction Management Environment. British Journal of Management , 23 (1), 65-79.

Ling, F. Y., \& Loo, C. M. (2013). Characteristics of Jobs and Jobholders that Affect Job Satisfaction and Work Performance of Project Managers. Journal of Management in Engineering.

Malik, M. E., Danish, R. Q., \& Munir, Y. (2012). The Role of Transformational Leadership and Leader's Emotional Quotient in Organizational Learning. World Applied Sciences Journal , 16 (6), 814-818.

Maloney, W. F., \& McFillen, J. M. (1986). Motivational Implications of Construction Work. Journal of Construction Engineering and Management , 112 (1), 137-151.

Maloney, W. F., \& McFillen, J. M. (1995). Job Characteristics: Union-Nonunion Differences. Journal of Construction Engineering and Management , 121 (1), 4354. 
Maric, M., Hernaus, T., Tadic, M., \& Cerne, M. (2019). Job Characteristics and Organizational Citizenship Behavior: A Multisource Study on the Role of Work Engagement. Dastvena Istrazivanja , 25-45.

Mo, Y., Dainty, A., \& Price, A. (2007). An Assessment Of The Emotional Intelligence Of Construction Students: An Empirical Investigation. Annual ARCOM Conference (pp. 325-334). Belfast, UK: Association of Researchers in Construction Management.

Morgeson, F. P. (2006). Handbook of Human Factors and Ergonomics. New Yark: John Wiley \& Sons, Inc.

Morgeson, F. P., Medsker, G. J., \& Campion, M. A. (2006). Job And Team Design. In G. Salvendy, Handbook of Human Factors and Ergonomics. Hoboken, NJ, USA: John Wiley \& Sons, Inc.

Naseer, Z., Chishti, S.-u.-H., Rahman, F., \& Jumani, N. B. (2011). Impact of Emotional Intelligence on Team Performance in Higher Education Institutes. International Online Journal of Educational Sciences , 3 (1), 30-46.

Oldham, G. R., \& Hackman, J. R. (2010). Not what it was and not what it will be: the future of job design research. Journal of Organizational Behavior , 31 (2), 463479.

Onukwube, H. N., \& Iyagba, R. (2011). Construction professionals job performance and characteristics: a Comparison of. Australasian Journal of Construction Economics and Building, 71-83.

Parker, S. K., Wall, T. D., \& Cordery, J. L. (2001). Future work design research and practice:Towards an elaborated model of work design. Journal of Occupational and Organizational Psychology, 413-440.

Piccolo, R. F., \& Colquitt, J. A. (2006). Transformational Leadership and Job Behaviors: The Mediating Role of Core Job Characteristics. Academy of Management Journal , 327-340.

Shahzad, K. (2011). Development Of A Model Of Organizational Citizenship Behavior (OCB): A Comparative Study Of University Teachers From A Developing And A Developed Country. Islamabad: Mohammad Ali Jinnah University.

Smyth, H. (2004). Competencies For Improving Construction Performance: Theories And Practice For Developing Capacity. The International Journal of Construction Management , 41-56.

Songer, A., Chinowsky, P., \& Butler, C. (2008). Leadership Behaviour In Construction Executives: Challenges For The Next Generation. Construction Information Quarterly, 10 (1), 59-66.

Sunindijo, R., \& Hadikusumo, B. (2014). Emotional Intelligence for Managing Conflicts in the Sociocultural Norms of the Thai Construction Industry." J. Manage. Eng., 10.1061/(ASCE)ME.1943-5479.0000211, 04014025. Journal of Management Engineering , 50-56. 
Sunindijo, R., Hadikusumo, B., \& Ogunlana, S. (2007). Emotional Intelligence and Leadership Styles in Construction Project Management." J. Manage. Eng., 10.1061/(ASCE)0742-597X(2007)23:4(166), 166-170. Journal of Management Engineering , 4 (166), 166-170.

Unuvar, T. G. (2006). An Integrative Model Of Job Characteristics, Job Satisfaction, Organizational Commitment, And. Phd Thesis, Middle East Technical University, Turkey, The Graduate School Of Social Sciences.

Zareen, M., Razzaq, K., \& Mujtaba, D. G. (2013). Job Design and Employee Performance: The Moderationg Role of Employee Psychological Perception. European Journal of Business and Management , 5 (3), 216-225.

Zhou, X. (2010). Assessment And Analysis Of Emotional Intelligence In Engineering Students. Masters Thesis, Clemson University. 